J. Perinat. Med. $16(1988) 93$

\section{Blood pressure measurements in very low birth weight infants over the first week of life}

\author{
David B. Shortland ${ }^{1}$, David H. Evans ${ }^{2}$, and Malcolm I. Levene \\ ${ }^{1}$ Neonatal Unit, Department of Child Health, and ${ }^{2}$ Department of Medical Physics, \\ Leicester Royal Infirmary, Leicester, England
}

\section{Introduction}

Recent advances in neonatal intensive care have dramatically improved the survival chances for the very low birth weight (VLBW) infant. Relatively more emphasis is now being placed on reducing the incidence of neurological handicap. Hypotension has been implicated as a contributory factor in cerebral ischemic injury [12] and the role of blood pressure monitoring is well established. Despite the importance of these measurements there have been only a few studies looking specifically at the range of blood pressure values found in the stable very low birth weight infants. We have reviewed retrospectively data on 32 such infants in an attempt to define a normal range for blood pressure.

\section{Methods}

Blood pressure monitoring was performed through a 4 or 5 FG Searle umbilical artery catheter positioned with its tip at $\mathrm{T} 8-10$, or through a radial or posterior tibial artery using a $24 \mathrm{G}$ cannula. The arterial lines were connected via low compliance tubing to an Elcomatic EM751A pressure transducer. Patency was maintained by infusing heparinized $5 \%$ dextrose solution at $1 \mathrm{ml} /$ $\mathrm{hr}$ through an Intraflo device as previously described [5]. The blood pressure waveform was recorded on a multi-channel chart recorder. The transducer was kept level with the midpoint of the infant's thorax and the calibration checked regularly. The frequency response of this system has been previously reported [5]. Systolic and diastolic blood pressure values were taken from the chart recordings at hourly intervals throughout the length of the recording. Any values taken when the trace was damped (no significant high frequency components) were ignored. These values were averaged over a 12 hour period. A mean blood pressure value was calculated by adding one-third of the pulse pressure to the diastolic value. Only complete 12 hour periods were analyzed.

The case notes of all of the infants who had continuous blood pressure monitoring were reviewed. In a proportion of infants a clinical decision was made to manipulate blood pressure using inotropic drugs or an infusion of plasma or whole blood, in situations where the infant's peripheral circulation was thought to be inadequate (eg oliguria or an increased core-peripheral temperature gradient). Blood pressure data from these infants were discarded from further analysis. The recordings were also excluded if the infant had received treatment known to influence the systemic blood pressure (eg tolazoline). The data were not included from episodes of cardiovascular collapse due to cardiac arrhythmias or pneumothoraces.

\section{Results}

Charts from a total of 51 infants were examined. Six infants were withdrawn from the study as inotropic drugs had been given because of a clinical deterioration in the baby's condition. Data from a further 2 infants were discarded for the first 24 hours of monitoring after they had been given fresh frozen plasma (FFP) to treat asymptomatic hypotension. In a third infant 24 hours of data was discarded after a bolus of $20 \mathrm{ml} / \mathrm{kg}$ of FFP was given to treat hypotension associated 
with a pneumothorax. One infant whose cranial ultrasound scan showed extensive parenchymal hemorrhage was also excluded. In a further 12 infants the chart recordings were inadequately labelled. Thirty-two infants were included in the final analysis. Twenty had birth weight up to 1250 grams (range $650 \mathrm{~g}$ to $1210 \mathrm{~g}$, median $1000 \mathrm{~g}$ ) and twelve had birth weight between 1251 and 1500 grams (range $1300 \mathrm{~g}$ to $1500 \mathrm{~g}$ ), median $1380 \mathrm{~g}$ ). The duration of monitoring ranged from 12 hours to 9 days (median 3.5 days). In all of the infants monitoring had begun within 60 hours of birth and in 14 infants it was begun within 12 hours of birth.

Twenty seven infants $(84 \%)$ received mechanical intermittent positive pressure ventilation for at least part of the time during which blood pressure recordings were made.

Figure 1 shows the average systolic, mean and diastolic blood pressure measurements for all infants throughout the study period. The infants are grouped according to birth weight: up to 1000 grams, $1001-1250$ grams and $1251-1500$ grams. There was no significant difference between blood pressure values in the infants les than 1000 grams and 1001-1250 grams (although the number of

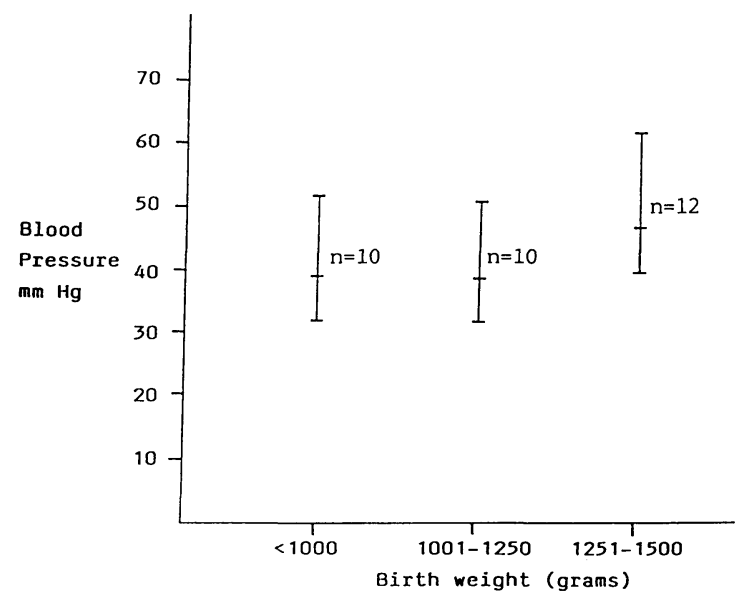

Figure 1. Derived mean blood pressures for the three groups of infants of varying birth weight averaged throughout the time of the study. The systolic, mean and diastolic values are represented by the upper, middle and lower bars respectively. The values for the infants of birth weight 1251-1500 grams are significantly higher than those for the infants of birth weight $\leqslant 1250$ grams (systolic $\mathrm{p}=0.0038$, mean $\mathrm{p}=0.0048$, and diastolic $\mathrm{p}=0.0019$ ). infants in these groups are small), and for the rest of the study these two groups are considered together. The infants of birth weight 1251-1500 grams (Group II) did, however, appear to have higher mean blood pressure values. Statistical analysis by the Mann-Whitney $U$ Test showed that the mean systolic $(\mathrm{p}=0.0038)$, mean $(\mathrm{p}=$ $0.0048)$ and diastolic $(\mathrm{p}=0.0019)$ blood pressure for this group as a whole were significantly higher than those for the infants of lower birth weights.

The mean blood pressure for each infant up to 1250 grams during each 12 hour period was plotted against time (figure 2). Insufficient infants were studied for more than 6 days to allow meaningful interpretation of blood pressure recordings after this time. Analysis using the Spearman rank pressure during the study period for these infants $(r=0.07)$. The mean blood pressure for the infants with birth weight $1251-1500$ grams did however show a significant increase with time ( $\mathrm{r}=0.34, \mathrm{p}<0.005)$.

The 12 hour averaged diastolic, mean and systolic blood pressure ( \pm 2 SD) for Group I was plotted against time (figure 3 ). These values are remarkably constant with diastolic blood pressure varying between $31 \mathrm{mmHg}$ and $34 \mathrm{mmHg}$, mean blood pressure between $35 \mathrm{mmHg}$ and $40 \mathrm{mmHg}$ and systolic blood pressure between $46 \mathrm{mmHg}$ and 52 $\mathrm{mmHg}$.

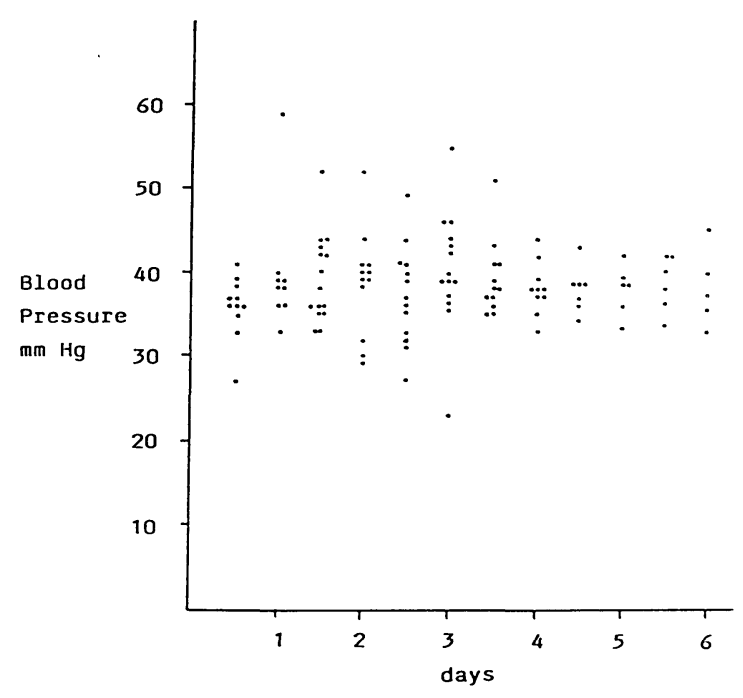

Figure 2. Values of derived mean arterial blood pressure with increasing postnatal age for infants of birth weights of up to $1250 \mathrm{~g}$. 


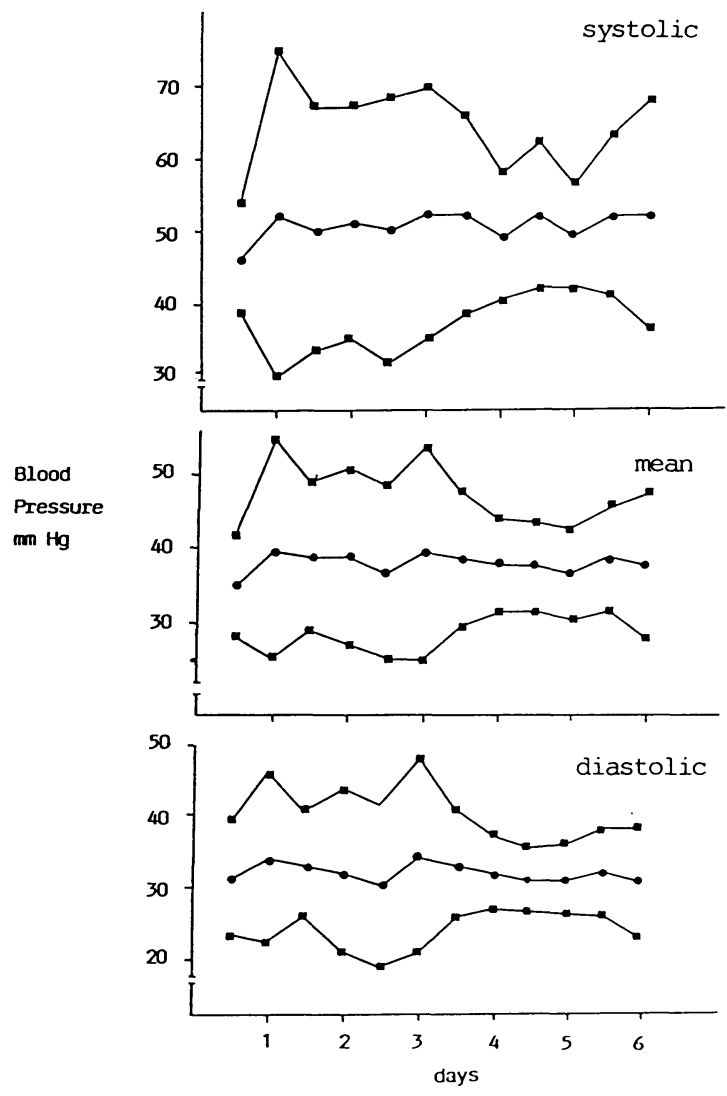

Figure 3. Ranges of blood pressure for infants of up to $1250 \mathrm{~g}$. Systolic, derived mean and diastolic values are represented by the upper, middle and lower diagrams respectively. The mean \pm 2 standard deviations are shown.

\section{Discussion}

Blood pressure is an extremely important clinical variable in the preterm infant and it can be measured conventiently and accurately through intraarterial lines $[2,5,10,11]$. We have analyzed the blood pressure values in 32 very low birth weight infants in an attempt to establish a normal range.

A number of studies have reported blood pressure values and trends in the neonatal period for term and preterm infants $[7,8,13]$. There is a close agreement between the values that these authors have reported and the values from the present study. There is general agreement that blood pressure increases as a function of birth weight $[6,8$, 13] but its relationship to gestational age is less well defined. A study by LEVISON et al. [9] showed no correlation between these two variables but in a detailed study of 186 low-birth weight infants by BuCCI et al. [3] it was shown that systolic blood pressure was independently related to body weight and gestational age. We have shown that the average systolic, mean and diastolic blood pressure for infants of birth weight up to 1250 grams is significantly lower than of infants with birth weight 1250-1500 grams.

Adams et al. [1] and Bucci et al. [3] have shown that blood pressure increases with increasing postnatal age. ADAMs et al. [1] showed that the increase was more marked in the least mature infants in the study. We did not find a significant increase in systolic or diastolic blood pressure with increasing postnatal age for the infants in Group I but there was a significant increase for those in Group II.

An infant's blood pressure is generally considered to be adequate when the urine output and peripheral-core temperature gradient are normal, but in the absence of clear guidelines to the contrary, it has been our policy to treat all infants with a systolic blood pressure consistently below 35 mmHg. In practice only 2 infants ( $6 \%$ of the total) were treated with FFP on the basis of a low systolic blood pressure reading alone. It is most unlikely that that this policy has significantly influenced the normal range that we report here.

Six infants were completely excluded from the study following an infusion of inotropic drugs. Three had received dopamine and tolazoline, 2 dopamine and bolus infusions of FFP and 1 had been given multiple infusions of FFP alone. In all of these infants we had deliberately manipulated the blood pressure to improve tissue perfusion and achieve an adequate urine output. We do not feel that the data from these infants would be at all helpful in establishing a normal range for blood pressure in the "stable" infant.

It has been suggested that extensive intraparenchymal cerebral hemorrhage may affect blood pressure. All infants in the study had had regular cranial ultrasound scans and in only one infant was there evidence of parenchymal hemorrhage. This infant was excluded from the study.

A considerable proportion of infants ( $84 \%)$ received intermittent positive pressure ventilation (IPPV) during the course of blood pressure monitoring. IPPV may affect blood pressure values, but we feel that as such a high proportion of VLBW infants will receive IPPV during the first few days of life, to exclude these infants would considerably limit the value of our study. 
Intra-arterial lines provide a convenient route for continuous blood pressure monitoring and the accuracy of this technique is well established [5]. Recent evidence [4] suggests that oscillometric monitors overestimate the blood pressure in hypotensive very low birth weight infants and intraarterial monitoring is the method of choice in these infants.

\section{Summary}

Intra-arterial blood pressure measurements recorded during the first week of life in 32 stable very low birth weight infants (20 of birth weight up to $1250 \mathrm{~g}$ and 12 with birgh weight $1251-1500 \mathrm{~g}$ ) were reviewed. None of the infants received inotropic drugs or were given infusions of colloids to manipulate the blood pressure during the periods from which the recordings were taken.

The mean systolic, mean and diastolic blood pressure measurements for infants of birth weight $>1250 \mathrm{~g}$ were significantly higher than those recorded in the infants of birth weight of up to $1250 \mathrm{~g}$ (figure 1). The mean blood pressure (calculated by adding one third of the pulse pressure to the diastolic pressure) in the larger infants showed a significant increase with increasing

postnatal age, but this increase was not apparent in the smaller infants (figure 2). Figure 3 shows the range of systolic, mean and diastolic blood pressure values that were recorded. The mean values were remarkably constant with diastolic blood pressure varying between 31 and $34 \mathrm{mmHg}$, mean blood pressure between $35 \mathrm{mmHg}$ and $40 \mathrm{mmHg}$, and systolic blood pressure between 46 $\mathrm{mmHg}$ and $52 \mathrm{mmHg}$.

Intra-arterial lines provide a convenient and accurate route for blood pressure monitoring. It is important that a normal range of blood pressure values in the very low birth weight infant is established so that hypotension, with the potential risk of cerebral ischemia, can be avoided.

Keywords: Arterial blood pressure, infant, postnatal changes.

\section{Zusammenfassung}

Blutdruckmessungen bei sehr kleinen Frühgeborenen während der ersten Lebenswoche

Wir berichten über intraarterielle Druckmessungen, die in den ersten 7 Lebenstagen bei 32 stabilen Frühgeborenen ( 20 mit einem Gewicht bis $1250 \mathrm{~g}$ und 12 von $1251-$ $1500 \mathrm{~g}$ ) aufgezeichnet wurden. Die Kinder erhielten weder inotrope Medikamente noch kolloidale Lösungen, die den Blutdruck während der Aufzeichnungsperioden beeinflussen könnten.

Der mittlere systolische und diastolische Druck war bei Kindern mit einem Geburtsgewicht oberhalb $1250 \mathrm{~g}$ signifikant höher als bei Kindern unterhalb $1250 \mathrm{~g}$ (Abb. 1). Der mittlere Blutdruck (gleich Summe aus $1 / 3$ des Pulsdruckes und diastolischem Druck) zeigte bei den größeren Kindern einen signifikanten Anstieg während der ersten Lebenstage. Dieser Anstieg war bei den kleineren Kindern nicht zu beobachten (Abb. 2). Abb. 3 zeigt die Meßreihen für den systolischen und diastolischen Druck sowie den Mitteldruck. Die Mittelwerte waren auffällig konstant bei diastolischen Werten zwischen 31 und $34 \mathrm{mmHg}$, Mitteldrucken zwischen 35 und 40 $\mathrm{mmHg}$ und systolischen Werten zwischen 46 und 52 mmHg.

Die intraarterielle Messung ist eine bequeme und genaue Methode zur Blutdrucküberwachung. Die Aufrechterhaltung normaler Blutdruckwerte ist bei sehr kleinen Frühgeborenen wichtig; so kann eine Hypotension mit dem Risiko einer zerebralen Ischämie vermieden werden.

Schlüsselwörter: Arterieller Druck, Kind, postnatale Veränderungen.

\section{Résumé}

Détermination de la pression artérielle chez les enfants de très faible poids de naissance au cours de la première semaine de vie

On a étudié les mesures de la pression sanguine intraartérielle enregistrée au cours de la première semaine de vie chez 42 enfants de très faibles poids de naissance ( 20 de poids de naissance de $1250 \mathrm{~g}$ et 12 de poids compris entre $1251 \mathrm{~g}$ et $1500 \mathrm{~g}$ ).

Aucun enfant n'avait reçu de médicaments inotropes ni l'avait reçu de perfusions de colloïdes en vue de réguler la pression artérielle pendant les périodes d'enregistrements.
Les mesures des pressions sanguines systoliques moyennes, diastoliques et moyennes chez les enfants de poids de naissance $>1250 \mathrm{~g}$ sont significativement plus élevées que celles enregistrées chez les enfants de moins de $1250 \mathrm{~g}$ (figure 1). La pression sanguine moyenne (calculée en ajoutant 1 tiers de la pression systolique à la pression diastolique) chez les enfants les plus gros montre une augmentation significative avec l'élévation de l'âge post-natal, mais cette augmentation n'est pas apparente chez les enfants les plus petits (figure 2). La figure 3 montre la distribution des valeurs des pressions enregistrées systolique moyenne et diastolique. Les valeurs 
moyennes sont remarquablement constantes avec une pression sanguine diastolique variant entre 31 et $34 \mathrm{~mm}$ $\mathrm{Hg}$, une pression sanguine moyenne entre 35 et $40 \mathrm{~mm}$ $\mathrm{Hg}$, et une pression sanguine systolique entre 46 et 52 $\mathrm{mm} \mathrm{Hg}$.

La voie intra-artérielle assure un moyen adapté et ap- proprié pour surveiller la pression sanguine. Il est important qu'une distribution normale des valeurs de la pression sanguine chez les enfants de très faible poids de naissance soit établie, de telle sorte que l'hypotension avec son risque potentiel d'ischémie cérébrale puisse être évitée.

Mots-clés: Enfant, pression artérielle, variations post-natales.

\section{References}

[1] Adams MA, JF Pasternak, BM Kupfer, TH GARDNER: A computerized system for continuous physiologic data collection and analysis; initial report on mean arterial blood pressure in very low birth-weight infants. Pediatrics 71 (1983) 23

[2] Baker MD, J Maisels, KH Marks: Indirect B. P. monitoring in the newborn - evaluation of a new oscillometer and comparison of upper- and lowerlimb measurements. Am J Dis Child 138 (1984) 775

[3] Bucci G, A Scalamander, PG Savignoni, M MenDicini, S Picece-BuCCI, L Piccinato: The system systolic blood pressure of newborns with low weight. Acta Pediatr Scand [Suppl] 229 (1972) 5

[4] Diprose GK, DH Evans, LNJ ARCHER, MI LEVENE: Dinamap fails to detect hypotension in very low birth weight infants. Arch Dis Child 61 (1986) 771

[5] Evans DH, GM Lark, LNJ Archer, MI Levene: The continuous measurement of intra-arterial pressure in the neonate; method and accuracy. Clin Phys Physiol Meas 7 (1986) 179

[6] Cupta JM, JW Scopes: Observations on blood pressure in newborn infants. Arch Dis Child 40 (1965) 637

[7] Hall RT, KO Oliver: Aortic blood pressure in infants admitted to a neonatal intensive care unit. Am J Dis Child 121 (1971) 145

[8] Kitterman JA, RH Phibbs, WH Tooley: Aortic blood pressure in normal newborn infants during the first 12 hours of life. Pediatrics 44 (1969) 959
[9] Levison H, BSL KIDd, PA Gemmell, PR Swyer: Blood pressure in normal full term and premature infants. Am J Dis Child 111 (1966) 374

[10] Lui K, PE Doyle, N Buchanan: Oscillometric and intra-arterial blood pressure measurement in the neonate; a comparison of methods. Aust Paediatr J 18 (1982) 32

[11] Meyer CL, EL Gresham, L Moyle, RD Jansen, AA LEMONS, RL SCHREINER: Evaluation of a system for continuous neonatal blood pressure monitoring. Crit Care Med 10 (1982) 689

[12] PAPE KF, JS WigglesworTh: Haemorrhage, ischaemia and the perinatal brain. Clinics in developmental medicine, Spastics International Medical Publications Vol 69/70, London 1979

[13] Versmold HT, JA Kitterman, RH Phibbs, GA GREGORY, WH TOOLEY: Aortic blood pressure during the first 12 hours of life in infants with birth weight 610 to 4220 grams. Pediatrics 67 (1981) 607

Received May 5, 1987. Revised August 21, 1987. Accepted October 12, 1987.

Dr. David Shortland

Pediatric Senior Registrar

The City Hospital

Huckrace Road

Nottingham, U. K. 


\section{Schneider · Lauritzen · Nieschlag Grundlagen und Kinik der menschlichen Fortpflanzung}

$17 \times 24 \mathrm{~cm}$. VIII, 1178 Seiten. Mit 388 Abbildungen. 1988. Gebunden DM 398,- ISBN 3110109689

In diesem Werk stellen Grundlagenforscher und Kliniker die Reproduktionsmedizin als interdisziplinäre ärztliche Aufgabe dar. Es werden sowohl die dominierenden Aspekte der Pathophysiologie aus der täglichen Praxis als auch das klinische Management der Fortpflanzungsstörungen bei Mann und Frau abgehandelt. Die Autoren sind ausgewiesene Experten in der experimentellen und klinischen Grundlagenforschung, die ihre langjährigen eigenen Erfahrungen aus der Klinik für die Praxis lesbar gemacht haben.

So wendet sich das Werk sowohl an den praktizierenden Arzt als auch an den forschenden Kliniker. Sein Ziel ist es, allen beteiligten Fachkollegen ein gemeinsames wissenschaftliches Fundament für weitere Forschungen und Erfolge in der Fertilitätsforschung zur Verfügung zu stellen.

Aufgrund des interdisziplinären Charakters dieses Werkes ist eine ganze Reihe medizinischer Fachgebiete direkt angesprochen: Frauenheilkunde und Geburtshilfe, Andrologie, Urologie, Dermatologie, Pädiatrie, Endokrinologie, Genetik, Immunologie und Allgemeinmedizin. 